\title{
Eastern Shoshone and Northern Arapaho Traditional Ecological Knowledge (TEK) and Ethnobotany for Wind River Reservation Rangelands
}

\author{
Colleen Friday ${ }^{1}$ and John Derek Scasta ${ }^{1 *}$ \\ ${ }^{1}$ Department of Ecosystem Science and Management, University of Wyoming, Laramie, USA. \\ *jscasta@uwyo.edu
}

\begin{abstract}
The need to affirm and revitalize cultural knowledge of native plant communities is imperative for Indigenous people. This ethnobotanical study documents Traditional Ecological Knowledge (TEK) structured from an Indigenous paradigm by exploring the connection between plants collected in two high-elevation basins and tribal members on the Wind River Indian Reservation (WRIR). We sought to qualitatively understand the plant resources by looking through the lens of Indigenous language and perspectives. Existing names of the basin plants in both the Eastern Shoshone and Northern Arapaho languages were compiled through an ethnobotanical literature review, seven in-person interviews with Eastern Shoshone and Northern Arapaho tribal members, and attendance at language workshops. We documented 53 Eastern Shoshone and 44 Northern Arapaho plant names, respectively. Historical impacts of past Federal Indian policy eras have shaped TEK as it currently exists within tribal communities. Both tribes used and had Indigenous names for Northern sweetgrass (Hierochloe hirta ssp. hirta), bitterroot (Lewisia rediviva), junipers (Juniperus ssp.), and bearberry or Kinnikinnick (Arctostaphylos uva-ursi). The resiliency of TEK is attributed to the perseverance of Indigenous people continuing to practice and teach traditions. The historical context specific to both the Eastern Shoshone and Northern Arapaho tribes and their languages are important for enhancing our current understanding of the ethnobotanical TEK of plants on the WRIR. Recognizing the value of ethnobotanical TEK and incorporating it into natural resource management plans and decisions can bridge diverse perspectives on land use for meaningful collaboration with tribal communities.
\end{abstract}

Received October 5, 2019

OPEN ठACCESS

Accepted March 2, 2020

Published May 11, 2020

DOI 10.14237/ebl.11.1.2020.1654

Keywords High-elevation basin, Ethnobotany, Eastern Shoshone, Northern Arapaho

Copyright (C) 2020 by the author(s); licensee Society of Ethnobiology. This is an open-access article distributed under the terms of the Creative Commons Attribution-NonCommercial 4.0 International Public License (https://creativecommons.org/licenses/by-nc/4.0), which permits non-commercial use, distribution, and reproduction in any medium, provided the original author and source are credited.

\section{Introduction}

Although Researchers, policy makers, and natural resource managers have begun to recognize the longterm value of Traditional Ecological Knowledge (TEK; also known as Indigenous Ecological Knowledge or IEK) for managing natural resources (Berkes et al. 2000; Davis and Ruddle 2010). TEK, as a way of knowing, is an accumulation of place-based knowledge, practice, and belief about relationships between living beings and their environment that is transferred to subsequent generations through Indigenous cultural practices (Berkes et al. 2000). Not all Indigenous members of a tribe have the same ecological knowledge base nor is it a standardized comprehensive account equally shared by all individuals. Generally, in Indigenous thought, people see themselves as families and communities instead of individuals (Aragon 2007; Miller 2009). Pierotti and Wildcat (2000:1335) said,

This way of thought includes: (1) respect for nonhuman entities as individuals, (2) the existence of bonds between humans and nonhumans, including incorporation of nonhumans into ethical codes of behavior, (3) the importance of local places, and (4) the recognition of humans as part of the ecological system, rather than as separate from and defining the existence of that system. 
The recognition of such bonds between humans and nature has also been shown for Indigenous people in many other countries (Clarke 2016; Wu 2015). Pierotti and Wildcat (2000) report that for many tribes, "[d] espite both forced and voluntary relocations, [they] have taken their TEK with them, which has allowed them to survive these experiences and establish sacred places in their new homes."

The role that plant communities have in Indigenous culture is a fundamental TEK concept with implications for climate change, food security, and natural resource management (Kuhnlein 2014; Reid et al. 2014). Conceptually quantifying the culturally important native plants can provide a unique lens to better understand Indigenous land use perspectives, as demonstrated by Davis (2019) for the Palouse prairie in the Pacific Northwest United States.

Globally, natural resource managers in crosscultural contexts have collaboratively created frameworks to incorporate TEK into adaptive management strategies in places, such as Australia, New Zealand, North America, and India (Flanagan and Laituri 2004; Holmes and Jampijinpa 2013; O'Donnell and Talbot-Jones 2018; Walsh et al. 2013). Such approaches may provide a more equitable role for American Indian tribes given the conflicted history with government (Whyte 2013). During the Reservation Era (1850s-1890s), tribal people were held on reservations and forbidden to practice tribal traditions, although this does not mean that people did not continue with traditions and ceremonies in secret (Wilkins and Stark 2017). The Assimilation Era (1870s-1930s) incorporated Christian ideologies and took children to off-reservation boarding schools. This government-imposed relocation obstructed oral transmission of cultural knowledge to future generations, which resulted in knowledge loss over time (Charbonneau-Dahlen et al. 2016).

TEK in the form of Indigenous languages has experienced parallel threats and resilience. During the Assimilation period, non-Indigenous linguists learned Indigenous languages and translated them into written forms (Cowell et al. 2014; Salzmann 1960). However, for Indigenous people, the combination of tribal children being prevented from learning Indigenous language, and the passing away of older generations of fluent speakers, led to the disappearance of numerous spoken Indigenous languages (Charbonneau-Dahlen et al. 2016).

The primary purpose of this study was to document the connection between plants in two highelevation basins with tribal members on the Wind River Indian Reservation (WRIR) by presenting taxonomically accurate scientific names coupled with tribal names and uses.

\section{Methodology \\ Study Area History}

The Eastern Shoshone and Northern Arapaho tribes reside on the WRIR of Wyoming. The 1868 Fort Bridger Treaty established the Shoshone Reservation for the Eastern Shoshone tribe (Trenholm and Carley 1964; WSHPO 2020). In 1878, the Northern Arapaho were placed temporarily on this reservation after the 1868 Treaty of Fort Laramie (Stamm 1999; Trenholm and Carley 1964). Placement of the Northern Arapaho at Wind River subsequently became permanent. The Eastern Shoshone tribe was compensated for the dividing of their reservation after a 1937 Supreme Court case against the US federal government (no tribes or state governments were named as defendants in the case) (Murray 1996; Shoshone Tribe of Indians v. United States 1937; Trenholm and Carley 1964) and the name of the reservation was changed to Wind River Indian Reservation (Trenholm and Carley 1964).

\section{Study Design}

Ethnobotanical information specific to the Eastern Shoshone and Northern Arapaho tribes was compiled through literature review, field sampling of voucher specimens, referencing archival documents, and interviews (Campbell n.d.; Cowell 2004; Martin 2010; Shimkin 1947). Our specific focus in this study was on two high-elevation basins that are of particular importance from an ethnobotanical perspective. A combination of researching linguistic sources and following up on information that tribal contacts provided was used to compile ethnobotanical information specific to the Eastern Shoshone and Northern Arapaho. We proceeded as follows: literature searches were conducted prior to interviews; translation occurred concurrently with native speakers when possible, through the use of written texts, and through consultation with other linguistic and/or plant experts as necessary; and plant pictures were offered during interviews as needed or requested. The ethnobotanical information gathered is not a comprehensive list of all historically-used plants by the Eastern Shoshone and Northern Arapaho people in the study area, but rather is on only plants identified in known vegetation inventory studies conducted in 
the Saint Lawrence and Paradise Basins. Linguistic sources included Shimkin's (1947) 1937-1938 ethnogeography study of the Wind River Shoshone, the Yellowstone National Park, Grand Teton National Park, and National Elk Refuge areas study (WSHPO 2020), the University of Colorado Arapaho Plant Names and Uses (Cowell 2004; Cowell et al. 2012, 2014), and North American Indian Medicinal and Food Uses Books (Shoshone and Arapaho; Moerman 2009 and 2010).

\section{Ethnobotany via In-person Interviews and Conversations}

In-person knowledge exchange was sought from elders in the Wind River tribal communities using human subject research methods approved by the University of Wyoming (UW) - Institutional Review Board (IRB; Protocol \#20171206CF01794). Seven individuals consisting of four Eastern Shoshone tribal members and three Northern Arapaho tribal members were interviewed about their general knowledge relating to plants or existing resources. This effort included the Eastern Shoshone Cultural Center located in Fort Washakie, WY. The tribal elder working at the center recommended the Eastern Shoshone working dictionary as a resource for plant names (Center et al. n.d.). In July 2018, a community contact recommended the Restoring Shoshone Ancestral Foods project as a source of information about plants traditionally used as food sources by Shoshone people. Meetings and informal trainings took place at the UW Cent\$ible Nutrition program of the WRIR Extension office in Fort Washakie, Wyoming. We visited the office and were provided information about the project as well as a list of the English common names of plant species and some of their uses and preparation processes, which corroborated knowledge previously collected from the literature review. In August 2018, an Eastern Shoshone tribal elder traveled to the research field site in Saint Lawrence basin and spent the day reviewing identified plants and reconciling them with entries in the Shoshone dictionary and his personal knowledge of the Shoshone language.

In March 2018, the lead researcher attended a two day Arapaho language workshop held at the University of Colorado (UC) Boulder. The workshop focused on techniques for teaching the language in western structured classrooms. Participants also had the opportunity to request elders to add words to the dictionary through providing them with an English word and its context so that the elders could formulate its name in Arapaho. In May 2018, a one day Arapaho language workshop was held at the Native American Education, Research, and Culture Center on the UW campus in Laramie, Wyoming. This workshop had a very low attendance due to a death of an Arapaho elder on the WRIR. In May 2018, an interested Northern Arapaho elder who did not know much about plants and their associated names referred me to online resources stored on the UC website. This online resource portal no longer exists at the time of this writing. The Arapaho names that were documented from the website were crosslisted and verified by the publication Plants and Plant Names in Arapaho Life and Language (Cowell 2004).

\section{Ethnobotanical Information for the Saint} Lawrence and Paradise Basins

\section{Plant Uses}

The methodology of plant collection such as season, frequency, and location will not be shared to protect the natural resource and tribal knowledge (Cowell 2004). Therefore, information regarding what plant parts are used and how they are gathered and prepared has been generalized and is applicable to both the Eastern Shoshone and Northern Arapaho tribes. The gathering and preparation processes of plants can be applied to individual plants used for food, medicinal, and/or ceremonial uses. Moerman (2010) listed approximately 32 plant food use categories. We note eight categories of traditional food use: beverage, seasoning, gravy, sweetener, preserves, vegetable, winter food, and starvation food (Cowell 2004; Moerman 2010).

Medicinal and ceremonial use information is restricted to individuals whom have received that knowledge through oral traditions, dreams, visions, or directly through cultural activities (Cowell et al. 2014; WSHPO 2020). Generalized medicinal use categories that are not deemed confidential include immune system booster, pain reliever, anti-inflammatory, cold remedy, pediatric aid, lung health, disease specific applications, and veterinary aid (Cowell 2004; Moerman 2009).

\section{Eastern Shoshone}

The classification of the Shoshone language is under the Uto-Aztecan language family as a Northern UtoAztecan, Central, Numic language (Miller 1984; Shimkin 1947). The Shoshone language consists of four dialects: Western, Northern, Eastern, and Goshute (Fowler 2009). For the Eastern Shoshone, 
we identified 53 total plant species (1 grass, 31 forbs, 17 shrubs, and 4 trees) found in the vegetation inventory of the two basins according to their common English name, scientific name, the Eastern Shoshone name, English translation of the Shoshone name, and/or whether the plant has any medicinal, food, traditional arts and crafts, casual, or ceremonial use to the Shoshone people (Table 1). The Shoshone names were phonetically spelled for ease of pronouncing the names by a non-fluent Shoshone speaking individual. Of the 53 plant species noted, 12 had some use documented but no Eastern Shoshone name, including: fireweed (Chamerion angustifolium) and antelope bitterbrush (Purshia tridentata) (food and medicinal use respectively). Some species were noted for more than three uses, including bastard toadflax (Comandra umbellata; tribal name unknown), common juniper (Juniperus communis; wah•pee), and limber pine

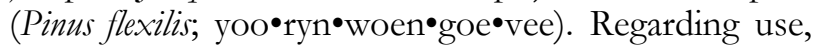
29 species had medicinal uses, ten species had food uses, ten species had traditional art and craft uses (including dye, nets, and arrows specifically), eight species had casual uses, and 30 species had ceremonial uses.

\section{Northern Arapabo}

The Arapaho language is one of four subdivisions of the traditional classification of the Algonquian language family and considered to be one of the three Great Plains Algonquian languages (Salzmann 1960). At some point the Arapaho language separated from the Algonquian family and has become quite different in its phonetics (Cowell et al. 2014). The way the Arapaho language adds prefixes and suffixes to a word stem forms long, complex words equivalent to English sentences, which can make translation difficult but can provide great linguistic insight (Cowell et al. 2014). The Arapaho language is further divided into Northern Arapaho (Wyoming) and Southern Arapaho (Oklahoma) (Cowell et al. 2014; Salzmann 1960). Although the Northern Arapaho were placed on the WRIR, there are names in the Arapaho language for Saint Lawrence basin (behii sio'buu noo, meaning "wash basin"). The ridge dividing Saint Lawrence from Paradise basin is called Windy Ridge (beet hee sei nii coo too yoo' meaning "windy hill"). These names indicate stories connected to place through their language and are intended as detailed descriptions.

For Northern Arapaho, we identified 44 total plant species (2 grasses, 1 grass-like, 26 forbs, 11 shrubs, and 4 trees) found in the vegetation inventory of the two basins according to their common English name, scientific name, the Northern Arapaho name, English translation, and plant uses (Table 2). Regarding use, 12 species had medicinal uses, 12 species had food uses, 12 species had traditional art and craft uses with several used for dye and one for arrows, three species had casual uses, and four species ( 2 shrubs and 2 trees) had ceremonial uses. Some plants had multiple Arapaho names such as common yarrow (Achillea millefolium; No'outihi'and Nonooke'einou'u), bitterroot (Lenisia rediviva; Neniicisoxu'oo' Wooxcoo'), and bearberry (Arctostaphylos wva-ursi; Noh'uwunobiise' Noh'uwuno) (Campbell n.d.; Cowell 2004).

\section{Comparison of Cultural Names and Uses}

Many plant species were found to have indigenous names from both tribes, but this was not always the case with variation between the tribes. For grasses and grass-like plants, both tribes had a name for Northern sweetgrass (Shoshone - bah $\bullet$ seep [bah may refer to water and seep may refer to willows and collectively may refer to locations where the plant can be found]; Arapaho - (s) No'oxu'and (p) ni'oxu'uno [translation "good grass"]) and medicinal and ceremonial use in common. Only the Arapaho had a general term for grass (Woxu') and a name for mountain rush (Juncus articus ssp. littoralis; Hotohine; translation unknown).

For forbs, both tribes recognized many of the same species (including common yarrow, nodding onion [Allium cernuum], wild chives [Allium schoenoprasum], sego lily [Calochortus nuttallii], bluebell bellflower [Campanula rotundifolia], fireweed, sulphurflower buckwheat [Eriogonum umbellatum var. majus], Virginia strawberry [Fragaria virginiana], elkweed or monument plant [Frasera speciosa], bitterroot, bluebells [Mertensia ciliata], and spearleaf stonecrop [Sedum lanceolatum]). Spearleaf stonecrop had indigenous names, translations, and uses for both tribes (Shoshone - oh•hah•yap [translation "yellow, has"]; Arapaho - Hoteibii3hiit [translation "sheep food"]). Even if a forb was recognized by both tribes, indigenous names were not necessarily determined in all cases. For example, for fireweed (Chamerion angustifolium), we determined an Arapaho name and translation (Xoowoo [translation "ceremonial lance"]) but could not determine a Shoshone name or translation. In some cases, both tribes recognized similar plants but with different levels of details about species such as for thistles (Cirsium species), 


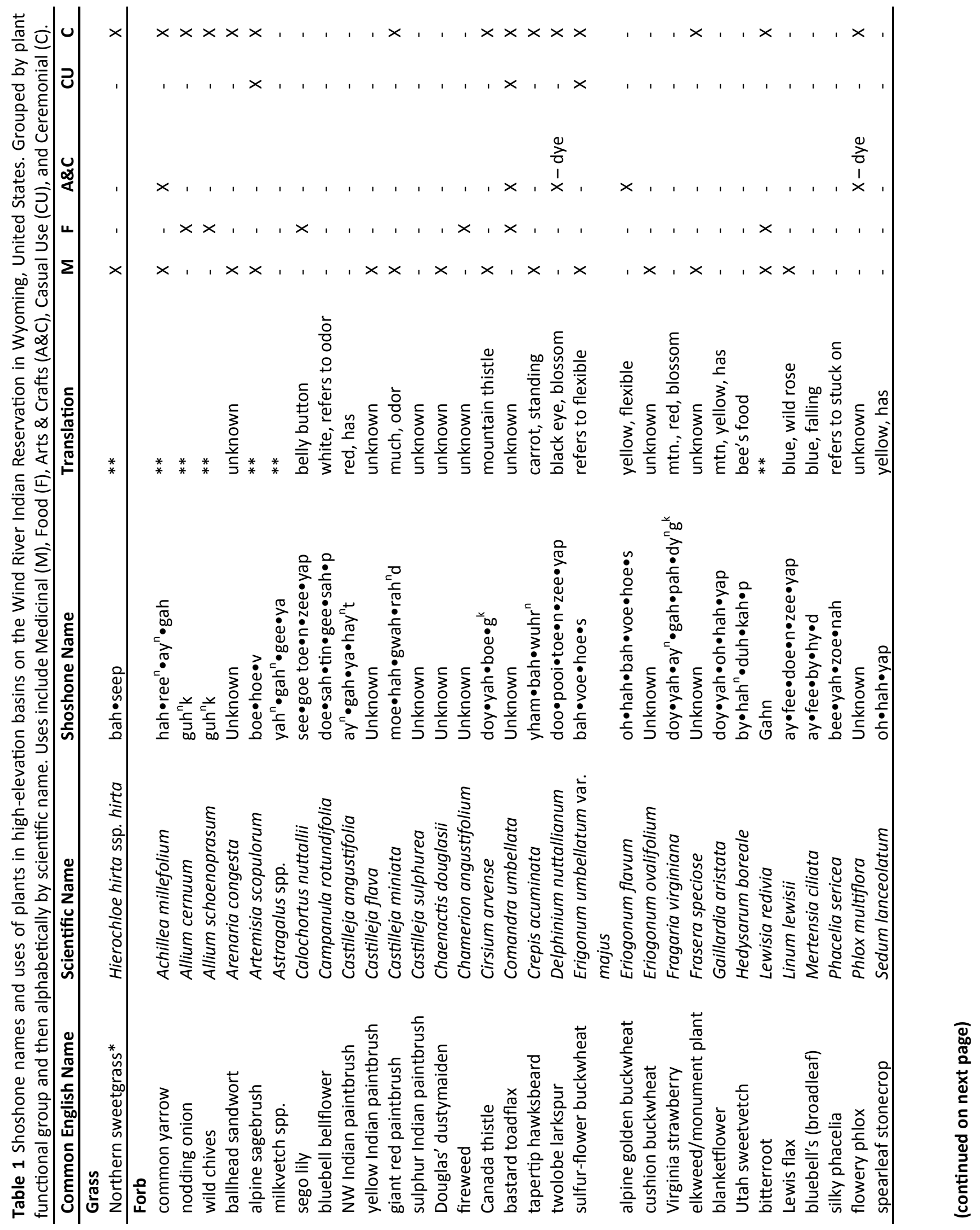


(f) EthNobiolocy Letters Data, Methods \& Taxonomies

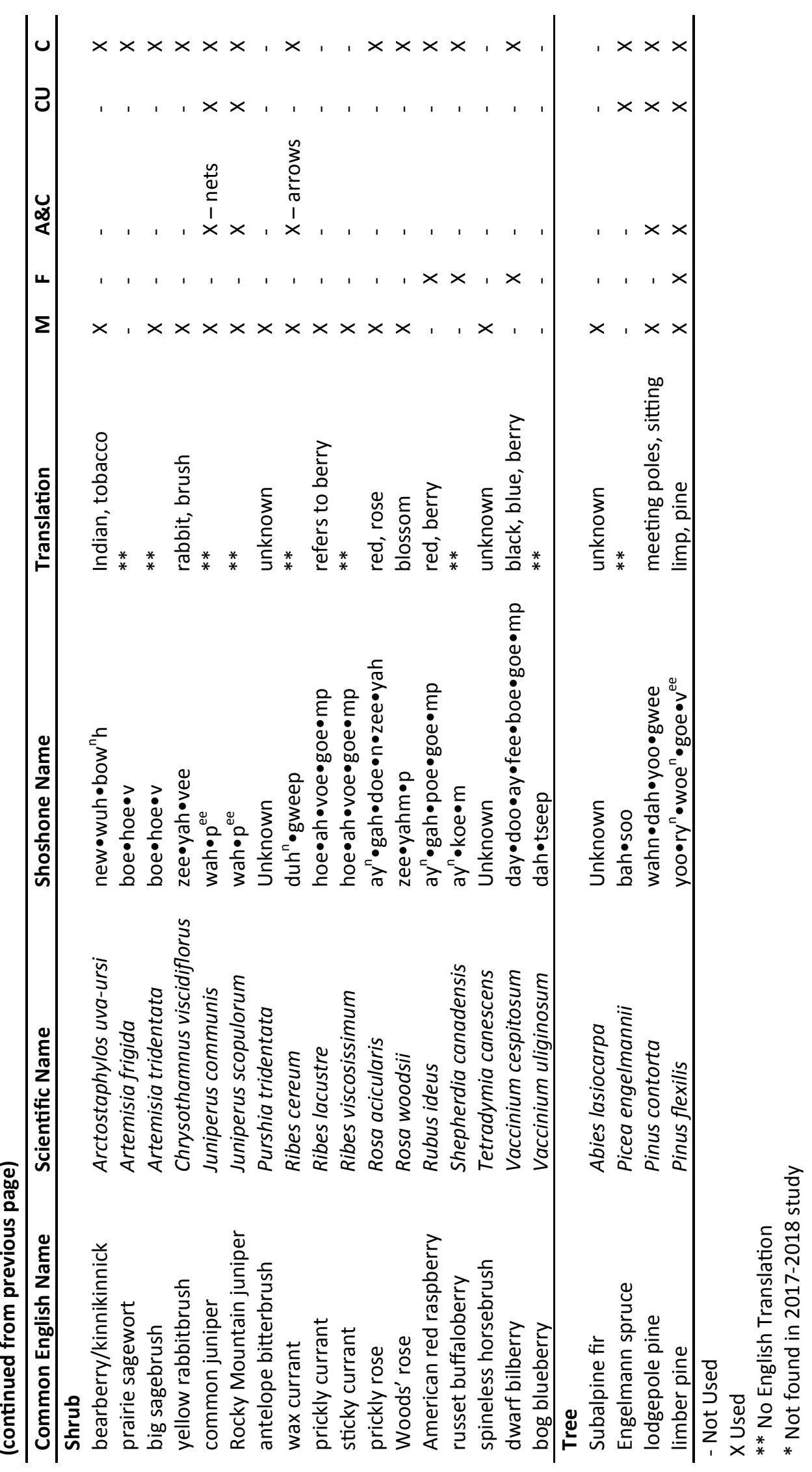


(1) Ethnobiolocy LetTers Data, Methods \& Taxonomies

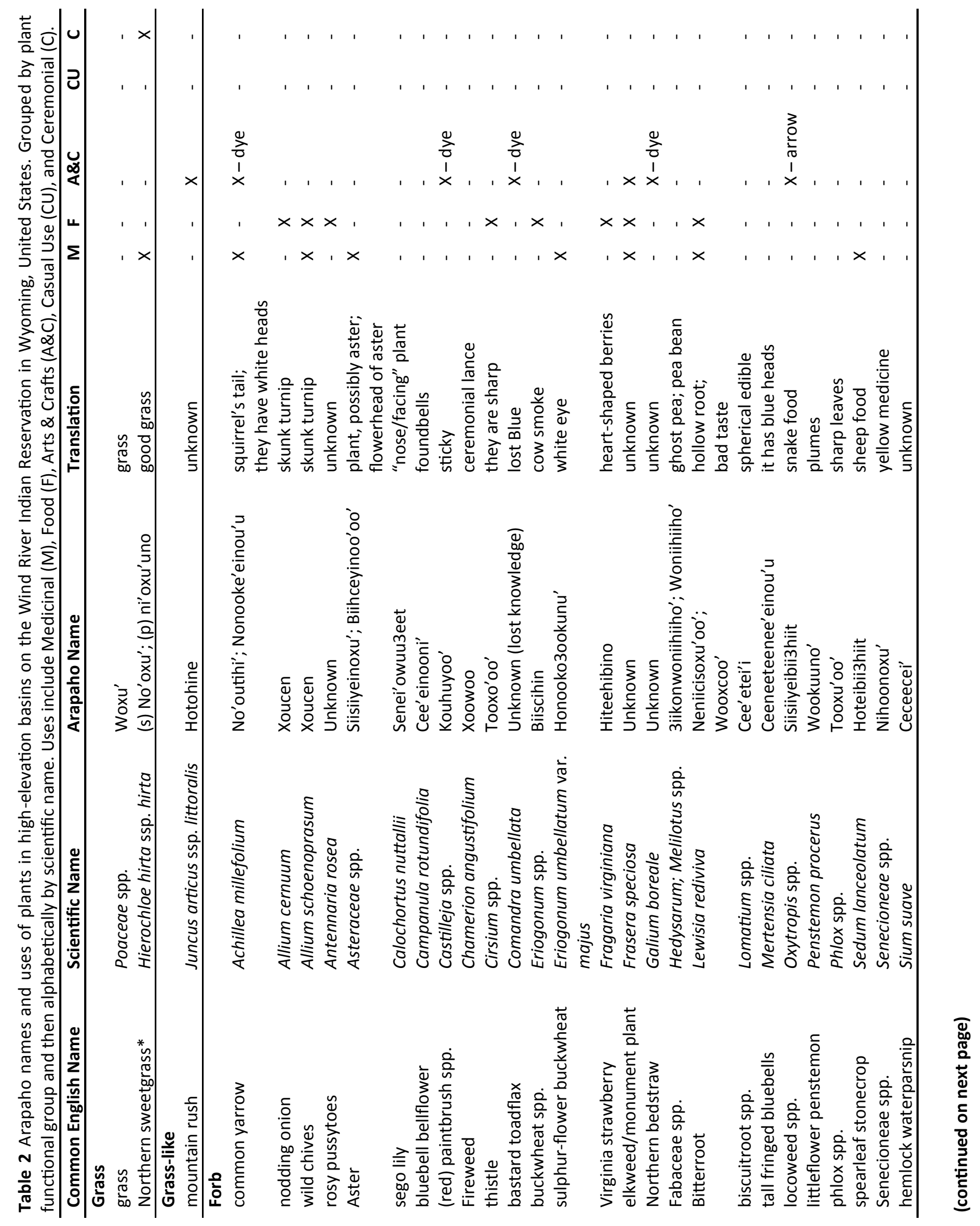


(f) Ethnobiolocy Letters Data, Methods \& Taxonomies

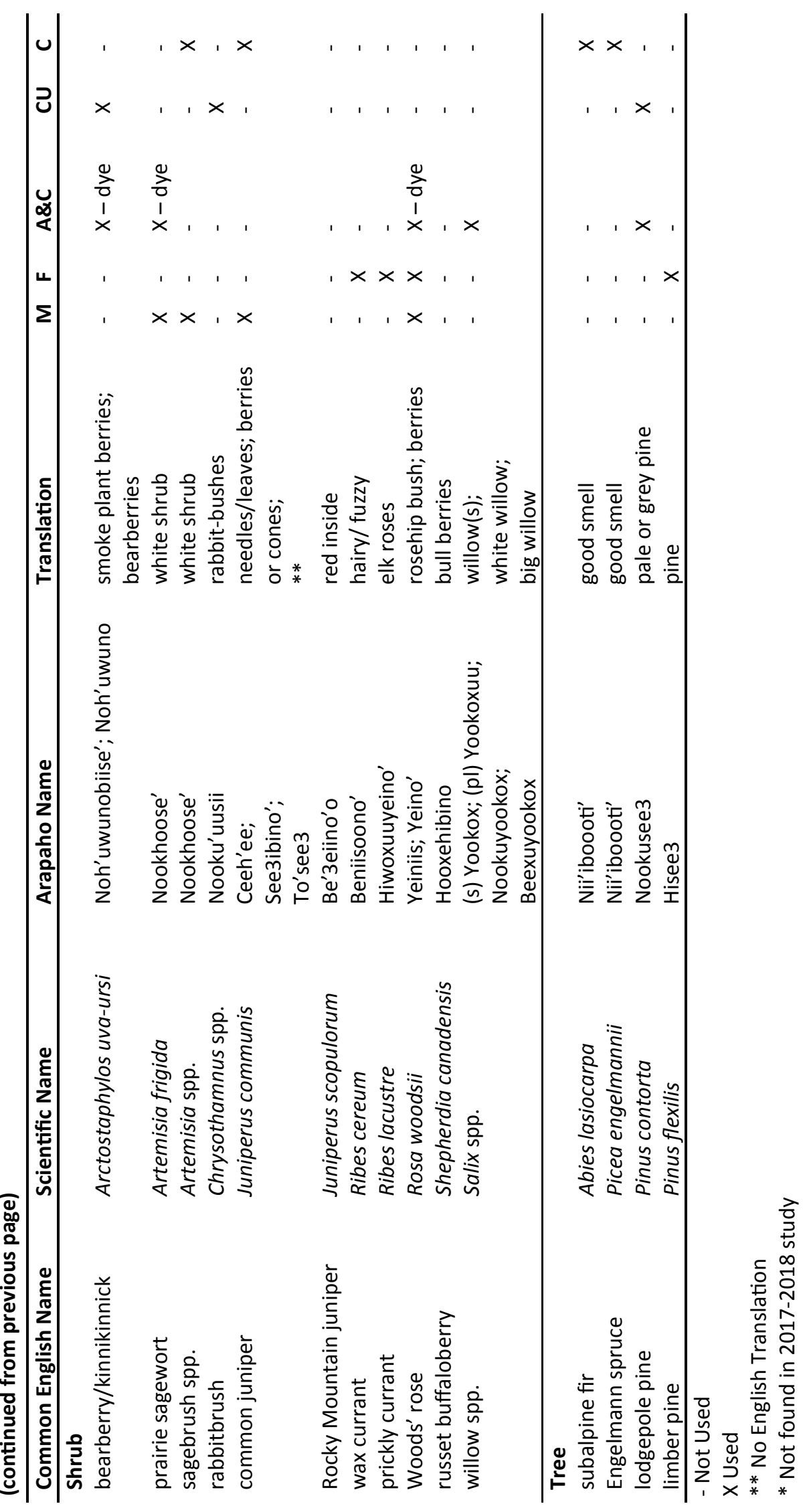


buckwheats (Eriogonum species), and phlox (Phlox species). For thistle as an example, one tribe recognized the plant generally (Arapaho Tooxo'oo' [translation "they are sharp"]) while the other tribe recognized the plant more specifically (Shoshone name for Canada thistle [Cirsium arvense] doy•yah•boe•gk [translation "mountain thistle"]). In some cases, only one tribe recognized a plant species with an indigenous name and use. For example, the Shoshone name for tapertip hawkbeard (Crepis acuminata), yham•bah•wuhrn translates as "carrot, standing;" and for twolobe larkspur (Delphinium nuttallianum), doo•pooi・toe-n•zee•yap translates as "black eye, blossom", but no names were found for Arapaho for these two species. Finally, for forbs, both tribes recognized a different genus of perennial legumes commonly recognized to be poisonous to cattle. Arapaho recognized locoweed generally (Oxytropis species) as Siisiiyeibii3hiit (translation "snake food) and Shoshone recognized milkvetch generally (Astragalus species) as yahn gahn•gee ya (translation unknown). Specific use of locoweed for arrows was indicated by the Arapaho.

For shrubs, all species recognized by Arapaho were also recognized by Shoshone with the exception of willows (Salix species; Western Shoshone includes terms for willows including sehepi, seep, etc.). The Arapaho had several names referring to willows ([s] Yookox, [pl] Yookoxuu, Nookuyookox, Beexuyookox) with different descriptions affiliated with different translations ("willow[s]", "white willow", "big willow"). Shrub species recognized by both tribes included bearberry, prairie sagewort (Artemisia frigida), sagebrush (Artemisia species although Shoshone specifically recognized big sagebrush [Artemisia tridentata]), rabbitbrush (Chrysothamnus species although Shoshone specifically recognized yellow rabbitbrush [Chrysothamnus viscidiflorus]), common juniper, Rocky Mountain juniper (Juniperus scopulorum), wax currant (Ribes cereum), prickly currant (Ribes lacustre), Wood's rose (Rosa woodsii), and russet buffaloberry (Shepherdia candensis). Both tribes use a single name for prairie sagewort and sagebrush (Shoshone - boe $\bullet$ hoe $\bullet$ v [translation unknown; pohopi means sagebrush in Western Shoshone]; Arapaho Nookhoose' [translation "white shrub”]). The translation for several shrub species was related to berries, as for example bearberry (Arapaho Noh'uwunobiise' and Noh'uwuno [translation "smoke plant berries", "bear berries"]), common juniper (Arapaho - See3ibino' [translation “berries or cones"]), and prickly currant (Shoshone hoe $\bullet$ ahoe $\bullet$ goe $\bullet$ mp [translation referring to berry; pokompih is Western Shoshone for currant or berry]). Both tribes indicated the use of bearberry for smoke or tobacco (Shoshone - new wuh•bownh [translation "Indian tobacco"]; Arapaho - Noh'uwunobiise [translation "smoke plant berries"]). Specific uses for shrubs included nets (Shoshone for common juniper), arrows (Shoshone for wax currant), and dyes (Arapaho for bearberry, prairie sagewort, and Wood's rose). Five shrub species were only recognized by the Shoshone.

For trees, both tribes recognized the same four species but translations and uses varied. For subalpine fir (Abies lasiocarpa), no Shoshone name or translation was found (evergreens in general are wonkopi[n] in Western Shoshone) and medicinal use was indicated, but Arapaho call it Nii'iboooti' (translation "good smell") and ceremonial use was indicated. For Engelmann spruce (Picea engelmannii), Shoshone call it bah•soo (translation unknown, although paso or pahso means sweet in Western Shoshone; casual and ceremonial use indicated) and Arapaho call it the same as subalpine fir with ceremonial use indicated. For lodgpole pine (Pinus contorta), Shoshone call it wahn•dah•yoo gwee (translation "meeting poles" and "sitting") with four of five use categories indicated; Arapaho call it Nookusee3 (translation "pale or grey pine") with arts/crafts and casual use indicated. For limber pine (Pinus flexilis), Shoshone call it yoo ryn *woen goe vee (translation "limp" and "pine") with all five use categories indicated; Arapaho call it Hisee3 (translation "pine") with food use indicated.

Our comparative findings demonstrate tribalspecific knowledge for different plants and their associated Indigenous names and uses. This is particularly relevant for the Wind River Indian Reservation, which is shared by the tribes and is important for restoration and preservation of each tribe's unique linguistic and traditional ecological knowledge.

\section{Conclusion}

Recognizing the value of Traditional Ecological Knowledge (TEK) in contemporary natural resource management can serve as a resource for additional studies. Definitions and broad examples of TEK, as well as the historical context of impacts of past Federal Indian policy eras such as Reservation and Assimilation, are essential to demonstrating how 
current TEK has been historically impacted and shaped. For example, this is likely why there are common and recognized plant species for which no tribal name has been confirmed. This study documented ethnobotanical TEK resources connecting the Eastern Shoshone and Northern Arapaho, respectively, to the plant communities of high-elevation basins of the WRIR. Historical context specific to each tribe and their languages gives fuller meaning to the 53 Eastern Shoshone and 44 Northern Arapaho names of plants that this study was able to compile for the Saint Lawrence and Paradise basins. With this qualitative resource available, future work on the WRIR could move to a more quantitative approach to better understand the individual variation across peoples to develop ethnobotanical TEK education strategies for future generations to further enhance cultural reclamation and preservation. TEK represents additional ways Indigenous people connect with land and resources and studies such as ours are critical because ethnobotanical uses, and understanding may be diminishing in the modern era.

\section{Acknowledgments}

We recognize and thank the members of the Eastern Shoshone and Northern Arapaho tribes on the Wind River Indian Reservation of Wyoming USA.

\section{Declarations}

Permissions: None declared.

Sources of funding: Funding provided by the Bureau of Indian Affairs (BIA) - Agreement Number

A17AC00019.

Conflicts of Interest: None declared.

\section{References Cited}

Aragon, D. 2007. The Wind River Indian Tribes. International Journal of Wilderness 13:14-17.

Berkes, F., J. Colding, and C. Folke. 2000. Rediscovery of Traditional Ecological Knowledge as Adaptive Management. Ecological Applications 10:1251-1262. DOI:10.1890/1051-0761(2000)010 [1251:ROTEKA]2.0.CO;2.

Campbell, G. R. n.d. Chapter 4: Arapaho Ethnobotany. Available at: http://theplantlady.net/resources/ Arapaho\%20Ethnobotany.pdf. Accessed on April 17,2020 .
Center, E. E., G. Gebow, S. S. Clair, and S. Shimkin. n.d. Eastern Shoshone Working Dictionary. Available at: http://easternshoshone.org/assets/easternshoshone-working-dictionary2.pdf. Accessed on April 17, 2020.

Charbonneau-Dahlen, B. K., J. Lowe, and S. L. Morris. 2016. Giving Voice to Historical Trauma Through Storytelling: The Impact of Boarding School Experience on American Indians. Journal of Aggression, Maltreatment \& Trauma 25:598-617. DOI:10.1080/10926771.2016.1157843.

Clarke, P. A. 2016. Birds as Totemic Beings and Creators in the Lower Murray, South Australia. Journal of Ethnobiology 36:277-294. DOI:10.2993/0278-0771-36.2.277.

Cowell, A. 2004. Plants and Plant Names in Arapaho Life and Language. University Press of Colorado, Boulder, CO.

Cowell, A., A. Moss, Wa. C'Hair, and Wi. C'Hair. 2012. Arapaho Immersion School, and Northern Arapaho elders, Dictionary of the Arapaho Language, 3rd edition. Northern Arapaho Tribe, Ethete, WY.

Cowell, A., A. Moss, and J. C. William. 2014. Arapaho Stories, Songs, and Prayers: A Bilingual Anthology. University of Oklahoma Press, Norman, OK.

Davis, C. 2019. The Palouse Prairie, a Vanishing Indigenous Peoples Garden. Journal of Native Sciences 1:1-17.

Davis, A., and K. Ruddle. 2010. Constructing Confidence: Rational Skepticism and Systematic Enquiry in Local Ecological Knowledge Research. Ecological Applications 20:880-894. DOI:10.1890/090422.1.

Flanagan, C., and M. Laituri. 2004. Local Cultural Knowledge and Water Resource Management: The Wind River Indian Reservation. Environmental Management 33:262-270. DOI:10.1007/s00267-0032894-9.

Fowler, C. 2009. Uto-Aztecan Languages. In Concise Encyclopedia of Languages of the World, edited by $\mathrm{K}$. Brown and S. Ogilivie, pp. 281-284. Elsevier, Oxford, UK. DOI:10.1016/B0-08-044854-2/02289 $-6$.

Holmes, M., and W. S. P. Jampijinpa. 2013. Law for Country: The Structure of Warlpiri Ecological Knowledge and Its Application to Natural Resource 
Management and Ecosystem Stewardship. Ecology and Society 18:19. DOI:10.5751/ES-05537-180319.

Kuhnlein, H. V. 2014. How Ethnobiology can Contribute to Food Security. Journal of Ethnobiology 34:12-28. DOI:10.2993/0278-0771-34.1.12.

Martin, G. J. 2010. Ethnobotany: A Methods Manual. Routledge, Abingdon, UK. DOI:10.4324/9781849775854.

Miller, W. R. 1984. The Classification of the UtoAztecan Languages Based on Lexical Evidence. International Journal of American Linguistics 50:1-24. DOI:10.1086/465813.

Miller, S. A. 2009. Native Historians Write Back: The Indigenous Paradigm in American Indian Historiography. Wicazo Sa Review 24:25-45. DOI:10.1353/wic.0.0018.

Moerman, D. E. 2009. Native American Medicinal Plants: An Ethnobotanical Dictionary. Timber Press, Portland, OR.

Moerman, D. E. 2010. Native American Food Plants: An Ethnobotanical Dictionary. Timber Press, Portland, OR.

Murray, L. G. 1996. Shoshone. In Encyclopedia of North American Indians, edited by F. E. Hoxie, pp. 586589. Houghton Mifflin Harcourt, Boston, MA.

O'Donnell, E., and J. Talbot-Jones. 2018. Creating Legal Rights for Rivers: Lessons from Australia, New Zealand, and India. Ecology and Society 23:7. DOI:10.5751/ES-09854-230107.

Pierotti, R., and D. Wildcat. 2000. Traditional Ecological Knowledge: The Third Alternative (Commentary). Ecological Applications 10:1333-1340. DOI:10.1890/1051-0761(2000)010[1333:TEKTTA] 2.0.CO;2.

Reid, M. G., C. Hamilton, S. K. Reid, W. Trousdale, C. Hill, N. Turner, and H. D. Matthews. 2014. Indigenous Climate Change Adaptation Planning Using a Values-Focused Approach: A Case Study with the Gitga'at Nation. Journal of Ethnobiology 34:401-425. DOI:10.2993/0278-0771-34.3.401.
Salzmann, Z. 1960. Two Brief Contributions Toward Arapaho Linguistic History. Anthropological Linguistics 2:39-48.

Shimkin, D. B. 1947. Wind River Shoshone Ethnogeography. University of California Press, Berkeley, CA.

Shoshone Tribe of Indians v. United States. 1937. 299 U.S. 476, No. 216, Supreme Court of the United States.

Stamm, H. E. 1999. People of the Wind River: The Eastern Shoshones, 1825-1900. University of Oklahoma Press, Norman, OK.

Trenholm, V. C., and M. Carley. 1964. The Shoshonis: Sentinels of the Rockies, no. 74. University of Oklahoma Press, Norman, OK.

Walsh, F., P. Dobson, and J. Douglas. 2013. Anpernirrentye: A Framework for Enhanced Application of Indigenous Ecological Knowledge in Natural Resource Management. Ecology and Society 18:18. DOI:10.5751/ES-05501-180318.

Whyte, K. P. 2013. On the Role of Traditional Ecological Knowledge as a Collaborative Concept: A Philosophical Study. Ecological Processes 2:7. DOI:10.1186/2192-1709-2-7.

Wilkins, D. E., and H. K. Stark. 2017. American Indian Politics and the American Political System. Rowman and Littlefield, Lanham, MD.

WSHPO. 2020. Wind River Indian Reservation Interpretive Plan for the Eastern Shoshone and Northern Arapaho. Wyoming State Historic Preservation Office. Available at: https://wyoshpo.wyo.gov/index.php/ files/834/Interpretive \% 20Plans/1241/Wind \% 20River\%20Interpretive\%20Plan.pdf. Accessed on April 17, 2020.

Wu, X. 2015. Wild Edible Plants and Pilgrimage on Wudang Mountain. Journal of Ethnobiology 35:606628. DOI:10.2993/etbi-35-03-606-627.1. 